\title{
Degradation of the pharmaceuticals lamivudine and zidovudine using advanced oxidation processes
}

\author{
Alex Leandro Andrade de Lucena ' ;Daniella Carla Napoleão " \\ Hélder Vinícius Carneiro da Silva "' ;Rayany Magali da Rocha Santana IV \\ Beatriz Galdino Ribeiro ${ }^{\mathrm{V}}$;Marta Maria Menezes Bezerra Duarte VI
}

\begin{abstract}
The existence of pharmaceuticals in nature is a growing environmental problem, turning necessary the use of efficient treatments for the degradation of these substances, as the advanced oxidation processes (AOPs). In this work the AOPs UV/ $\mathrm{H}_{2} \mathrm{O}_{2}$ and photo-Fenton were applied to degrade the pharmaceuticals lamivudine and zidovudine in an aqueous solution using a bench reactor, composed of three UV-C lamps. It was verified that the $\mathrm{UV} / \mathrm{H}_{2} \mathrm{O}_{2}$ process presented a degradation of $97.33 \pm 0.14 \%$ for lamivudine and $93.90 \pm 0.33 \%$ for zidovudine, after 180 min of treatment and for an initial concentratin of each pharmaceutical of $5 \mathrm{mg} \cdot \mathrm{L}^{-1}$ and $\left[\mathrm{H}_{2} \mathrm{O}_{2}\right]$ of $600 \mathrm{mg} \cdot \mathrm{L}^{-1}$. A methodology by artificial neural networks (ANNs) was used to model the photocatalytic process, with the MLP 7-23-2 ANN representing it well, and determining the relative importance (\%) of each of the input variables for the pharmaceutical's degradation process. Kinetic studies for the pharmaceutical degradation and the conversion of organic matter showed good adjustments to the pseudo first-order models with $\mathrm{R}^{2}$ raging from 0.9705 to 0.9980 . Toxicity assays for the before treatment solution indicated that the seeds Lactuca sativa and Portulaca grandiflora showed growth inhibition whereas the post-treatment solution inhibited only the growth of Lactuca sativa.
\end{abstract}

Keywords: AOPs; ANNs; HPLC; Kinetic modeling; Lamivudine toxicity; UV/H2O2; Zidovudine

\footnotetext{
I Federal University of Pernambuco, Recife, Brazil. lucenaalex3@gmail.com

" Federal University of Pernambuco, Recife, Brazil. danicarlan@gmail.com

III Federal University of Pernambuco, Recife, Brazil. heldervcs@gmail.com

IV Federal University of Pernambuco, Recife, Brazil. rayanymagalirocha@gmail.com

${ }^{\vee}$ Federal University of Pernambuco, Recife, Brazil. beatrizgaldinoribeiro@gmail.com

${ }^{v 1}$ Federal University of Pernambuco, Recife, Brazil. mmmbduarte@gmail.com
} 


\section{INTRODUCTION}

The pharmaceutical compounds comprise a large group of human and veterinary medicinal products used everyday (KLAVARIOTI et al., 2009). Among the various classes of these products are the antiretrovirals. This class covers drugs that are used in the treatment of influenza, human immunodefiency virus (HIV), herpes and hepatitis. (ZHOU et al., 2015). From the 1990s, when they started to be marketed, the use of antiretroviral drugs grew rapidly around the world, mainly because of their efficiency in the treatment of the HIV virus (CAMPONESCHI et al., 2013).

In the class of antiretrovirals drugs, the most commonly used are lamivudine (3TC), zidovudine (AZT), abacavir, nevirapine and stavudine. Usually these drugs or a combination of at least two of them are applied in the treatment of the acquired immunodeficiency syndrome (AIDS)(KUMARI; SINGH, 2012).Zidovudine was the first antiretroviral drug approved and marketed for the treatment of HIV, while lamivudine was the first approved in the treatment of hepatitis(KUMARI; SINGH, 2012; BURKE; MARKS, 2017).

However, like other pharmaceuticals, these compounds have generated concern, since when not completely metabolized they are excreted via urine and feces, then following the sewage collection networks to wastewater treatment plants (WWTP), where the usual physical-chemical and biological treatments are not effective for their complete removal, enabling these contaminants to reach surface waters. (ZHOU et al., 2015). These substances can also reach the receiving bodies through the disposal of pharmaceutical industries effluents, from the production processes (CHRISTOU et al., 2017; EBELE et al., 2017).

Lamivudine and zidovudine are examples of antiretrovirals that have already been identified in treatment plants for effluents, rivers and other types of surface water around the world, with some studies in Europe (PRASSE et al., 2010; AMINOT et al., 2015; VERGEYNST et al., 2015a, 2015b), but mainly in Africa (K'OREJE et al., 2012; WOOD et al., 2015; K'OREJE et al., 2016; NGUMBA et al., 2016; SCHOEMAN et al., 2017; MADIKILEZA et al., 2017; WOOD et al., 2017). This is due to the AIDS outbreak on the African continent where, in 2015, the number of patients living in constant antiretroviral 
therapy against HIV in the regions of East Africa and Southern Africa totaled 10.2 million people. This figure is approximately 7 times higher than in Western and Central Europe and North America, with about 1.4 million people (UNAIDS, 2016).

Once the presence of these substances in the environment has been verified, and considering their adverse effects (genotoxicity, endocrine distuption in animals and in humans), these compounds have come to be considered a growing environmental problem throughout he planet (AQUINO et al., 2013; RODRIGUEZNARVAEZ et al., 2017). Unlike other types of organic pollutants, the pharmaceuticals contaminants are released to the environment constantly, their surces act in a continuous way and their use accompanies population growth, causing them to be observed in greater concentration on nature over the years (PAÍGA et al., 2014; CHRISTOU et al., 2017; EBELE et al., 2017).

Since lamivudine and zidovudine present in surface waters are not completely removed at conventional wastewater treatment plants, it was developed a study, in Germany, by Prasse et al. (2010), showing that for aerobic and anaerobic WWTP, these drugs had a removal of $76 \%$ and $68 \%$, respectively. Knowing this and that antiretroviral drugs are among the most dangerous pharmaceuticals. Because of their toxicity to algae and fish, which can generate alterations in the ecosystems, besides the possibility of synergistic and mutagenic effects occurring in both aquatic fauna and humans, it is necessary to evaluate the efficiency of alternative treatments that are capable of efficiently degrade these compounds (SANDERSON et al., 2004; BOTTONI et al., 2010).

Among the possible treatments to be employed are the advanced oxidation processes (AOP). These involve the production and application of hydroxyl radicals, characterized by being higly reactive, which act by completely oxidizing complex organic compounds, converting them to carbon dioxide, water and mineral salts (BRANDT et al., 2017; MIRZAEl et al., 2017). Differrent types of advanced oxidation processes have been used in the treatment of water and effluents, the most common being $\mathrm{UV} / \mathrm{H}_{2} \mathrm{O}_{2}$ and photo-Fenton processes(RIBEIRO et al., 2015; SERPONE et al.,2017). 
The UV/ $\mathrm{H}_{2} \mathrm{O}_{2}$ process consist in the addition of hydrogen peroxide $\left(\mathrm{H}_{2} \mathrm{O}_{2}\right)$ in the presence of ultraviolet (UV) light to promote the generation of hydroxyl radicals $(\bullet \mathrm{OH})$, which are capable of oxidizing pollutants such as the pharmaceutical contaminants. Another important factor in the use of $\mathrm{UV} / \mathrm{H}_{2} \mathrm{O}_{2}$ process is that UV radiation can alsoactas a disinfectant, physically inactivating the microorganisms present in the study matrix (AMETA; AMETA, 2018). The photo-Fenton process involves the reaction between $\mathrm{Fe}^{2+} / \mathrm{H}_{2} \mathrm{O}_{2}$ and $\mathrm{Fe}^{3+} / \mathrm{H}_{2} \mathrm{O}_{2}$, in the presence of UV radiation and/or visible light, with iron ions being the reaction catalysts (LINDEN; MOHSENI, 2014).

Studies involving the application of different types of AOPs have shown that the $\mathrm{UV} / \mathrm{H}_{2} \mathrm{O}_{2}$ and photo-Fenton processes are very efficient technologies in the removal of pharmaceutical contaminants from the environment (WANG, 2016). Some of these studies involving the use of AOP in the treatment of pharmaceutical contaminants are set forth in Table 1.

Table 1 - Works using UV/H2O2 and photo-Fenton process for the degradation of pharmaceutical contaminants in aqueous medium

\begin{tabular}{|c|c|c|c|c|c|c|}
\hline Process & Pharmaceutical & Radiation & $c_{0}$ & $\begin{array}{c}\text { Time of } \\
\text { exposure }\end{array}$ & Degradation & References \\
\hline \multirow[b]{3}{*}{$\mathrm{UV} / \mathrm{H}_{2} \mathrm{O}_{2}$} & Oxcarbazepine & UVC & $10 \mu g \cdot L^{-1}$ & $10 \mathrm{~min}$ & $90 \%$ & Liu et al. (2018) \\
\hline & Propranolol & UVC & $\underset{1}{20} \underset{\mu g}{ } \mathrm{~L}^{-}$ & $30 \mathrm{~min}$ & $80 \%$ & $\begin{array}{l}\text { Yang et al. } \\
\text { (2019) }\end{array}$ \\
\hline & $\begin{array}{c}\text { Erofloxacin, } \\
\text { Perfloxacin and } \\
\text { Sulfaquinoxaline }\end{array}$ & UVC & $\begin{array}{l}1 \mathrm{~g} \cdot \mathrm{L}^{-1} \\
1 \mathrm{~g} \cdot \mathrm{L}^{-1} \\
\text { and } \\
4 \mathrm{mg} \cdot \mathrm{L}^{-1}\end{array}$ & $180 \mathrm{~min}$ & $\begin{array}{c}100 \%, 79,1 \% \\
\text { and } 100 \%\end{array}$ & Qiu et al. (2019) \\
\hline \multirow{3}{*}{$\begin{array}{l}\text { photo- } \\
\text { Fenton }\end{array}$} & Venlafaxine & $\begin{array}{l}\text { UV-B/ } \\
\text { UV-A }\end{array}$ & $\begin{array}{c}100 \\
\mathrm{mg} \cdot \mathrm{L}^{-1}\end{array}$ & $180 \mathrm{~min}$ & $95 \%$ & $\begin{array}{c}\text { Giannakis et al. } \\
(2017)\end{array}$ \\
\hline & Carbamazepine & Solar & $15 \mathrm{mg}_{1}^{\mathrm{L}^{-}}$ & $5 \mathrm{~min}$ & $100 \%$ & $\begin{array}{l}\text { Expósito et al. } \\
\text { (2018) }\end{array}$ \\
\hline & Ampicillin & Solar & $\begin{array}{c}100 \\
\mu g \cdot L^{-11}\end{array}$ & $20 \mathrm{~min}$ & $100 \%$ & $\begin{array}{l}\text { Ioannou-Ttofa } \\
\text { et al. (2019) }\end{array}$ \\
\hline
\end{tabular}


Table 1 shows the efficiency of the $\mathrm{UV} / \mathrm{H}_{2} \mathrm{O}_{2}$ and photo-Fenton processes in the degradation of the most varied types of pharmaceutical contaminants, in different initial concentrations in the studied medium. For both analyzed processes, degradations above $79 \%$ were obtained.

The classical approaches in studies involving advanced oxidation processes are established for investigating factors or components, which are varied one by one. While this approach provides a good overview of a system's response, it often overlooks the interactions between different factors and the implications that link them together. In addition, models derived from such processes may provide an adequate but limited predicted description (GIANNAKIS et al., 2017). To avoid this problem, to obtain conclusions with greater reliability and simplicity, as well as to overcome small error and noise factors, an artificial neural network (ANN) modeling can be used when evaluating the efficiency of AOPs (BEKKARI and ZEDDOURI, 2018).

ANNs are mathematical models with a higher performance, good prediction for nonlinear systems and can be applied in pharmaceutical research for different purposes. These include estimation, forecasting, simulation and classification (ARABZADEH et al., 2019; MORIJl et al., 2019).

When working with the advanced oxidation processes for the treatment of the most varied types of contaminants, besides analyzing the parameters involved in the process, their efficiency and their kinetics, other factors that must be considered are the intermediates and products formed during the degradation processes. Since they may be more toxic to the environment than their original compounds (SALVADOR et al., 2012). Thus, conducting a toxicity assessment, after the application of the AOP, becomes a crucial step to evaluate the applicability of the process (HUANG et al., 2017). Different types of organisms can be used in these tests, like microorganisms, plants, algae, invertebrates and even fish, in order to evaluate the multiple reactions that a contaminant can cause in a medium/biota (ESCHER et al., 2011; PUNZI et al., 2015).

In this context and knowing that treatment processes for removal of the lamivudine and zidovudine drugs are still few studied when compared to other 
classes more commonly used as antibiotics and anti-inflammatories (FUNKE et al., 2016); this work aimed to propose the treatment by photo-Fenton process and $U V / \mathrm{H}_{2} \mathrm{O}_{2}$ action for an aqueous mixture of the drugs lamivudine and zidovudine. To perform a kinetic study monitoring the percentages of degradation, drug concentration values and chemical oxygen demand (COD) over time. To evaluate the effectiveness of the treatments through a mathematical modeling using artificial neural networks (ANNs). In addition, to evaluate the toxicity of solutions before and after submission to the AOP treatments, using seeds of Lactuca sativa (lettuce) and Portulaca grandiflora (eleven hours flower).

\section{MATERIALS AND METHODS}

\subsection{Determination of the pharmaceuticals by UV/Vis spectrophotometry}

Two solutions containing $1000 \mathrm{mg} \cdot \mathrm{L}^{-1}$ of the pharmaceuticals lamivudine and zidovudine were prepared separately by weighing $100 \mathrm{mg}$ of each of the active principles and dissolving in a mixture of distilled water and methanol 9:1. For the dilutions of the analytical curve points as well as for the working solution, the stock solution was diluted with distilled water only. The solutions were qualitatively analyzed in a UV/Vis spectrophotometer (THERMOSCIENTIFIC), at the wavelengths of 267 and $271 \mathrm{~nm}$. For both $\lambda$, analytical curves with linearity ranges of 1 to $10 \mathrm{mg} \cdot \mathrm{L}^{-1}$ and from 10 to $100 \mathrm{mg} \cdot \mathrm{L}^{-1}$ were used, with correlation coefficients above 0,999 and values of LOD and LOQ equal to $0.8013 \mathrm{mg} \cdot \mathrm{L}^{-1}$ and $2.4281 \mathrm{mg} \cdot \mathrm{L}^{-1}$ for lamivudine and $0.7049 \mathrm{mg} \cdot \mathrm{L}^{-1}$ and $2.136 \mathrm{mg} \cdot \mathrm{L}^{-1}$ for zidovudine.

\subsection{Degradation of the pharmaceuticals using advanced oxidation processes}

Initially, degradation tests were performed by comparing the photoFenton $\left(\mathrm{H}_{2} \mathrm{O}_{2} / \mathrm{Fe}^{2+} / \mathrm{UV}\right)$ and $\mathrm{UV} / \mathrm{H}_{2} \mathrm{O}_{2}$ processes using a factorial design $2^{3}$, with a central point in triplicate, in order to evaluate the most efficient process to degrade the pharmaceuticals and their best working conditions. For this, a bench reactor was 
used, composed of three UV-C lamps, arranged in parallel, each with a power of 30W and photons emissions of $1,98 \cdot 10^{-3} \mathrm{~W} \cdot \mathrm{cm}^{-2}$ (employing radiometer, Emporionet), Figure 1 . The reactor is internally coated with aluminum foil.

Figure 1 - Experimental scheme of UV-C reactor, with measurements in centimeters

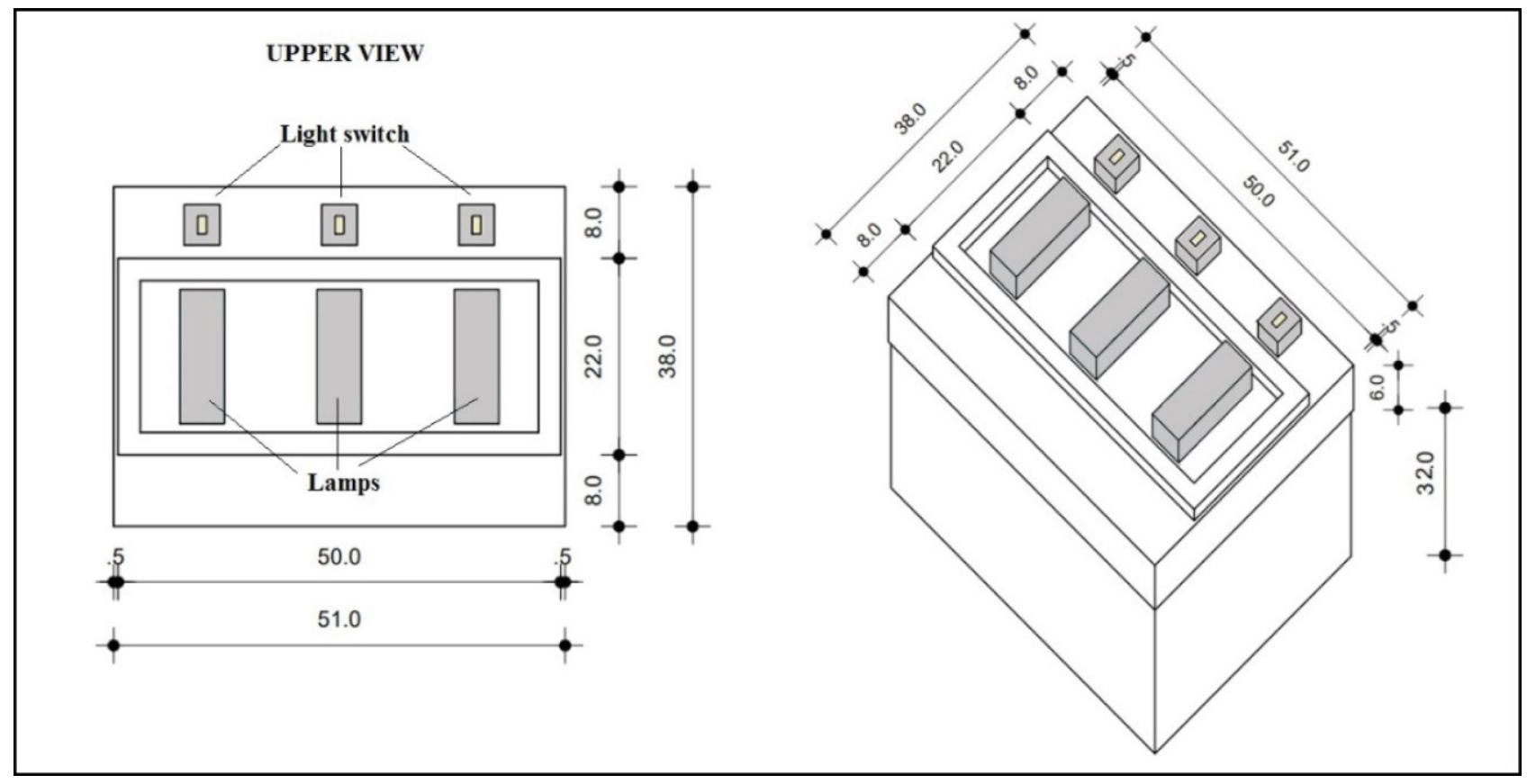

Source: Zaidan et al. (2017).

To perform the factorial design, beakers were used containing $50 \mathrm{~mL}$ of an aqueous solution of the two pharmaceuticals in a mixture at a concentration of 30 $\mathrm{mg} \cdot \mathrm{L}^{-1}$ each, with the treatment lasting 60 minutes. The analyzed variables were $\mathrm{pH}$, iron concentration ([Fe]) and the hydrogen peroxide concentration $\left(\left[\mathrm{H}_{2} \mathrm{O}_{2}\right]\right)$. The efficiency of the applied AOP was evaluated as a function of the degradation percentage of both pharmaceuticals under study, considering their characteristic wavelengths using the UV/Vis spectrophotometry. The planning matrix employed in the work, as well as the maximum and minimum levels for each variable are shown in Table 2. Tests $1,2,5$ and 6 refer to the $\mathrm{UV} / \mathrm{H}_{2} \mathrm{O}_{2}$ process, while tests 3,4 and from 7 to 11 employed the photo-Fenton process with two different concentrations of iron. It is noteworthy that there was no displacement of the wavelength in the $3 \mathrm{pH}$ ranges studied. 
Table 2 - Planning matrix for factorial $2^{3}$ with center point in triplicate

\begin{tabular}{lccc}
\hline Experiment & {$\left[\mathrm{H}_{2} \mathbf{O}_{2}\right]\left(\mathbf{m g} \cdot \mathrm{L}^{-1}\right)$} & {$[\mathrm{Fe}]\left(\mathrm{mg} \cdot \mathrm{L}^{-1}\right)$} & $\mathbf{p H}$ \\
\hline 1 & $-1(40)$ & $-1(0)$ & $-1(3-4)$ \\
2 & $+1(120)$ & $-1(0)$ & $-1(3-4)$ \\
3 & $-1(40)$ & $+1(5)$ & $-1(3-4)$ \\
4 & $+1(120)$ & $+1(5)$ & $-1(3-4)$ \\
5 & $-1(40)$ & $-1(0)$ & $+1(5-6)$ \\
6 & $+1(120)$ & $-1(0)$ & $+1(5-6)$ \\
7 & $-1(40)$ & $+1(5)$ & $+1(5-6)$ \\
8 & $+1(120)$ & $+1(5)$ & $+1(5-6)$ \\
9 & $0(80)$ & $0(2,5)$ & $0(4-5)$ \\
10 & $0(80)$ & $0(2,5)$ & $0(4-5)$ \\
11 & $0(80)$ & $0(2,5)$ & $0(4-5)$ \\
\hline
\end{tabular}

Based on the results of the factorial design, the most efficient AOP was selected, alongside with the determination of its significant variables. The need to investigate in a more detailed way the influence of $\left[\mathrm{H}_{2} \mathrm{O}_{2}\right]$ on the degradation of the drugs was also identified. For this, experiments were performed using concentrations of $100,200,300,400,500$ and $600 \mathrm{mg} \cdot \mathrm{L}^{-1}$ of $\mathrm{H}_{2} \mathrm{O}_{2}$ for the degradation of $50 \mathrm{~mL}$ of a pharmaceuticals solution containing lamivudine and zidovudine at $30 \mathrm{mg} \cdot \mathrm{L}^{-1}$, over a period of 60 minutes.

The influence of the addition form of hydrogen peroxide in the process was also evaluated. The $\mathrm{H}_{2} \mathrm{O}_{2}$ was added in two different ways: the entire volume at once at time 0 for the first run and in the second one the volume was fractionated into 3 equal aliquots, added at the times of 0,10 and 20 minutes. The increase on the contact surface between the solution and the radiation was also evaluated, by changing the working solutions volume from $50 \mathrm{~mL}$ to $1 \mathrm{~L}$. 
After all these parameters were defined, the aqueous solution was degraded using different concentrations of the pharmaceuticals: $5,10,15$ and $30 \mathrm{mg} \cdot \mathrm{L}^{-1}$, with aliquots being removed at the times of $60,90,120,150$ and 180 minutes, to assess the influence of time on the degradation process.

\subsection{Kinetic study and modeling}

Based on the best experimental conditions for the treatment of the pharmaceuticals by the AOP, experiments were carried out to determine the degradation kinetics, with monitoring by UV/Vis spectrophotometry, as well as the evolution of organic matter conversion through the chemical demand of oxygen (COD). To do this, $1 \mathrm{~L}$ of solution containing about $5 \mathrm{mg} \cdot \mathrm{L}^{-1}$ of the pharmaceuticals was irradiated for 240 minutes, with regular withdrawals of $5 \mathrm{~mL}$ aliquots at the times of 5 , $10,15,20,25,30,35,40,45,50,60,75,90,120,150,180,210$ e 240 minutes. The COD was determined according to the spectrophotometric method, following the procedure described in the 5220D method of the Standard methods for the examination of water and wastewater (APHA, 2012).

Once the concentration at each point of the kinetic evaluation was determined, the modeling of the process could be performed using the pseudo-first order model, developed by Chan and Chu (2003), Equation 1.

$$
C=C_{0} \cdot\left(1-\frac{t}{\rho+\sigma t}\right)
$$

In which, $C$ is the pharmaceutical concentration $\left(\mathrm{mg} \cdot \mathrm{L}^{-1}\right)$ after the AOP treatment at time $t(\mathrm{~min}), C_{0}$ is the initial concentration of pharmaceutical $\left(\mathrm{mg} \cdot \mathrm{L}^{-1}\right)$ and the parameters $\frac{1}{\rho}$ and $\frac{1}{\sigma}$ represent, respectively, the velocity constant $\left(\mathrm{min}^{-1}\right)$ and the oxidative capacity of the system (dimensionless). The values of the $\rho$ and $\sigma$ constants were found from the linearization of Equation 1, according to Equation 2. 
$\frac{t}{\left(1-\frac{c}{c_{0}}\right)}=\rho+\sigma t$

By constructing a graph of $t /\left(1-\frac{c}{c_{n}}\right)$ versus $t$, it was obtained a straight line, where the angular and linear coefficients correspond, respectively, to $\rho$ and $\sigma$.

Then, COD decay was evaluated based on a pseudo-first order model that takes into account the initial and final concentrations of COD over time, Equation 3 (RAJKUMAR, PALANIVELU, 2004).

$-\ln \left(\frac{D Q O_{0}}{D Q O}\right)=k t$

Where, $\mathrm{k}$ is the rate constant $\left(\mathrm{min}^{-1}\right)$ for the organic matter conversion process.

\subsection{Evaluation of the AOP treatment efficiency by high performance liquid chromatography analysis}

The AOP treatment efficiency was assessed by high performance liquid chromatography (HPLC) analysis. For this, an HPLC-Shimadzu SS-550 equipment equipped with the ULTRA C18 column ( $\mu \mathrm{m} ; 4,6 \times 250 \mathrm{~mm}$ ), operating in reverse phase and an ultraviolet/visible (UV/Vis) spectrophotometric detector was used. The chromatographic system used in the equipment employed a mobile phase consisting of acetonitrile and acetic acid acidified water p.a (35:65).

A stock solution of the pharmaceuticals at a concentration of $1000 \mathrm{mg} \cdot \mathrm{L}^{-1}$ was prepared and from this, two analytical curves were built (from 1 to $10 \mathrm{mg} \cdot \mathrm{L}^{-1}$ and from 10 to $\left.100 \mathrm{mg} \cdot \mathrm{L}^{-1}\right)$.

To analyze the efficiency of the AOP for the degradation of the drugs under study, a solid-liquid extraction (SLE) was performed for later HPLC analysis. The SLE process was performed using Strata-X polymeric cartridges $(500 \mathrm{mg} / 6 \mathrm{~mL}$ Phenomenex) operating in reverse mode, according to Napoleão et al. (2018). 
Artificial neural networks were applied to verify the influence of operational parameters along the degradation process of the lamivudine and zidovudine pharmaceuticals, using Statistica 8.0 software. The networks used employed methodologies with Multilayer Perceptron (MLP) and Radial Basis Function (RBF) configurations, comprising three layers (input, hidden intermediate and output), with the number of neurons in the hidden layer ranging from 4 to 28. The training algorithm was based on Broyden, Fletcher, Goldfarb and Shanno (BFGS) methods and the transfer functions tested were identity, logistic, tangential, hyperbolic, sine and exponential. The input variables consisted of pharmaceutical concentration (mg.L $\left.{ }^{-1}\right)$, $\left[\mathrm{H}_{2} \mathrm{O}_{2}\right]\left(m g \cdot \mathrm{L}^{-1}\right)$, $[\mathrm{Fe}]\left(m g \cdot \mathrm{L}^{-1}\right), \mathrm{pH}$, time $(\mathrm{min})$, volume $(\mathrm{mL})$ e $\mathrm{H}_{2} \mathrm{O}_{2}$ addition. Thus, an analysis of each parameter relevance in the pharmaceutical's degradation was performed using 171 experimental data to feed the network, in addition to 1000 iterations and 10 replicates, with randomized sampling and data divided into 15\% for validation, $15 \%$ for test and $70 \%$ for training. The best results were bases on the smallest errors and the highest values for linear regression $\left(R^{2}\right)$ obtained for validation, testing and training.

\subsection{Toxicity Assessment}

The toxicity was evaluated using Lactuta sativa (lettuce) and Portulaca grandiflora (eleven hour flower) seeds. These were exposed to solutions at different concentrations of the pharmaceuticals, before and after the treatment with advanced oxidation processes.

For the treated pharmaceutical solutions (post treatment solutions - PTS) volumetric concentrations were used in the ranges of: $1,5,10,50,70$ and $100 \%$. Petri dishes and filter papers were used as the carrier medium in the assays, where the seeds and a $2 \mathrm{~mL}$ aliquot of each solution were placed. All analyzes were performed in triplicate (NAPOLEÃO et al., 2018). The positive and negative control were, respectively, a $3 \%$ boric acid solution and water, at the same volume of the pharmaceuticals solutions; The samples were kept in an environment with the absence of light and at a temperature of $25 \pm 1^{\circ} \mathrm{C}$ during a period of $72 \mathrm{~h}$. Then, the 
number of seeds that germinated in each of the plates and the root growth of the seeds were observed. From this, the relative growth index (RGI) and the germination index (Gl) were calculated according to Equations 4 and 5, respectively (YOUNG et al., 2012).

$R G I=\frac{R L S}{R L C}$

$G I(\%)=\mathrm{RGI} \cdot \frac{(G S S)}{(G S C)} \cdot 100$

Where, RLS is the total root length in the sample, RLC is the total root length in the negative control, GSSis the number of germinated seeds of the sample and GSC is the number of seeds germinate in the negative control.

\section{RESULTS AND DISCUSSION}

\subsection{Degradation of the pharmaceuticals using advanced oxidation processes}

For a better evaluation of the data obtained in the degradation of the pharmaceuticals involving the photo-Fenton and $\mathrm{UV} / \mathrm{H}_{2} \mathrm{O}_{2}$ processes, a $2^{3}$ factorial design, with a central point in triplicate, was applied. From it, the main effects and their interactions of 2 and 3 factors of the studied variables were calculated using the Statistica 8.0 software. By applying Pareto chars, Figure 3, it was possible to verify which variables and factors were statistically significant with $95 \%$ confidence.

Figure 3 - Pareto charts: (a) Lamivudine (pure error $=0,91125$ ) and (b) Zidovudine (pure error $=0,80645$ ) 


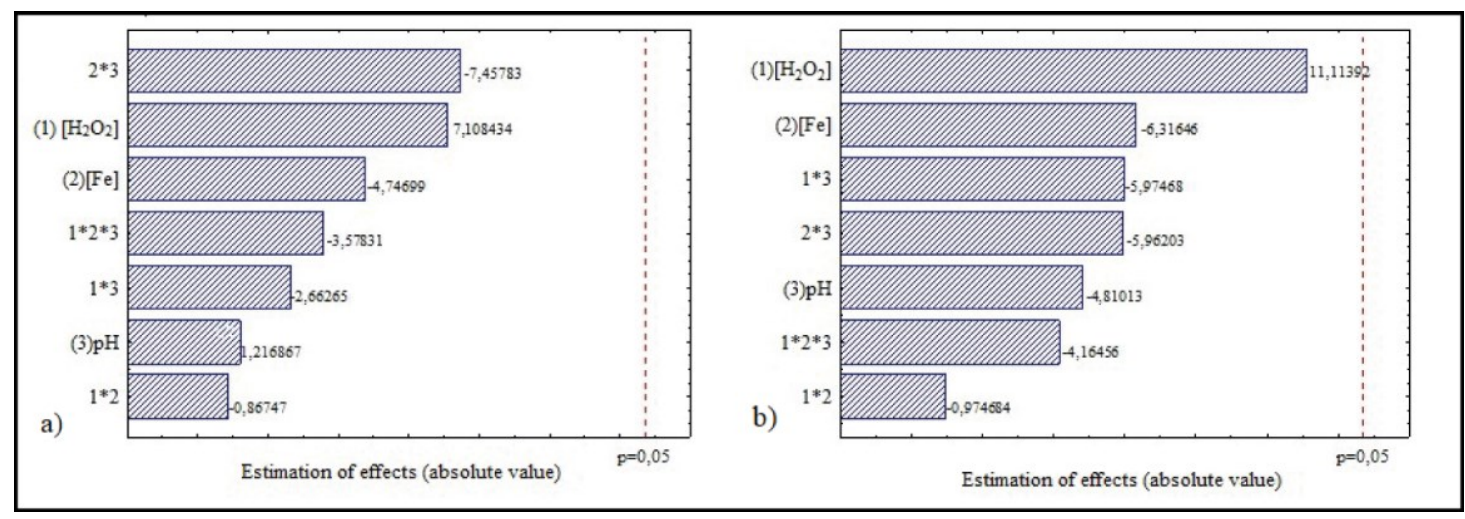

The analysis of Figure 3 shows that none of the effects was statistically significant since they did not exceed $\mathrm{p}=0.05$, at the studied levels. The $\mathrm{UV} / \mathrm{H}_{2} \mathrm{O}_{2}$ process showed a higher degradation efficiency for both drugs and this process is independent of [Fe] and $\mathrm{pH}$. The results indicate that the assay number 6 obtained the best degradation result for both pharmaceuticals, being performed under $\mathrm{pH}$ conditions between 5-6 (natural solution), without iron and $\left[\mathrm{H}_{2} \mathrm{O}_{2}\right]$ of $120 \mathrm{mg} \cdot \mathrm{L}^{-1}$, in which it was possible to degrade $11.28 \%$ of lamivudine and $11.05 \%$ of zidovudine. Thus, a univariate study the $\left[\mathrm{H}_{2} \mathrm{O}_{2}\right]$ was conducted, using different concentrations of this reagent in the degradation of both pharmaceuticals by the $U V / H_{2} \mathrm{O}_{2}$ process and to determine the concentration range with greater degradation capacity. The results of this analysis are set out in Table 4.

Table 4 - Degradation via UV/ $\mathrm{H}_{2} \mathrm{O}_{2}$ process by varying the $\mathrm{H}_{2} \mathrm{O}_{2}$ concentration for 60 minutes 
400

500

600
21.85

27.94

37.10
19.77

26.12

35.38

The results presented in Table 4 indicate that at the concentration of $600 \mathrm{mg} \cdot \mathrm{L}$ 1 of $\mathrm{H}_{2} \mathrm{O}_{2}$, the highest degradation for both pharmaceuticals occurs, with values exceeding 35\%.However, these values are still low, so some changes were made in the assays. The first one consisted in modifying the addition form of $\mathrm{H}_{2} \mathrm{O}_{2}$ in the samples. According to Tiburtius et al. (2009) this reagent is consumed in a short period of time and it is not advisable to add the whole concentration at once. In this way, the concentration of $600 \mathrm{mg} \cdot \mathrm{L}^{-1}$ was fixed and the degradation of the pharmaceuticals analyzed for 60 minutes, substituting the single addition of hydrogen peroxide for a fractional addition at the times of 0,10 and 20 minutes. This change increased the degradation values of lamivudine to $62.34 \%$ and zidovudine to $63.12 \%$.

The same procedure was then repeated, however, instead of using $50 \mathrm{~mL}$ beakers $\left(13.85 \mathrm{~cm}^{2}\right)$, a glass container with a capacity of $1.5 \mathrm{~L}\left(400 \mathrm{~cm}^{2}\right)$ and $1 \mathrm{~L}$ of the pharmaceutical solution was used, in order to increase the contact area of the solution with the ultraviolet radiation during the $\mathrm{UV} / \mathrm{H}_{2} \mathrm{O}_{2}$ process. The exchange of containers increased the degradation of the lamivudine to $88.01 \%$ and of zidovudine to $87.72 \%$.

Finally, assays were performed using $600 \mathrm{mg} \cdot \mathrm{L}^{-1}$ of $\left[\mathrm{H}_{2} \mathrm{O}_{2}\right]$, with fractional addition in the times of 0,10 and 20 minutes, volume of the working solution of $1 \mathrm{~L}$ and different initial concentrations of the drugs under study were evaluated $(5,10,15$ and $\left.30 \mathrm{mg} \cdot \mathrm{L}^{-1}\right)$, in order to verify their effect on the degradation. In addition, the radiation exposure time was varied, with aliquots of the solutions being withdrawn at times of $60,90,120,150$ and 180 minutes. The results of these degradations are shown in Table 5. 
Table 5 - Degradation of the pharmaceuticals via UV/ $\mathrm{H}_{2} \mathrm{O}_{2}$ process

\begin{tabular}{|c|c|c|c|c|}
\hline \multirow{2}{*}{ Time (min) } & \multicolumn{4}{|c|}{ Initial pharmaceutical concentration } \\
\hline & $5 \mathrm{mg} \cdot \mathrm{L}^{-1}$ & $10 \mathrm{mg} \cdot \mathrm{L}^{-1}$ & $15 \mathrm{mg} \cdot \mathrm{L}^{-1}$ & $30 \mathrm{mg} \cdot \mathrm{L}^{-1}$ \\
\hline & \multicolumn{4}{|c|}{ \% Lamivudine degradation } \\
\hline 60 & 81.79 & 85.40 & 86.37 & 88.01 \\
\hline 90 & 85.37 & 88.55 & 89.36 & 90.60 \\
\hline 120 & 87.81 & 89.43 & 89.94 & 91.05 \\
\hline 150 & 89.27 & 90.31 & 90.61 & 91.28 \\
\hline \multirow[t]{2}{*}{180} & 90.49 & 90.94 & 91.19 & 91.72 \\
\hline & \multicolumn{4}{|c|}{$\%$ Zidovudine degradation } \\
\hline 60 & 78.21 & 82.84 & 83.87 & 87.72 \\
\hline 90 & 82.72 & 86.97 & 88.35 & 90.51 \\
\hline 120 & 85.98 & 88.52 & 89.22 & 91.14 \\
\hline 150 & 87.73 & 89.42 & 89.99 & 91.62 \\
\hline 180 & 89.23 & 90.45 & 90.77 & 91.84 \\
\hline
\end{tabular}

The analysis of Table 5 shows that although the degradation rate for the lowest concentration of pharmaceuticals $\left(5 \mathrm{mg} \cdot \mathrm{L}^{-1}\right)$ is lower in the first 60 minutes of the process, after a period of 180 minutes a percentage of degradation similar to that of the highest concentrations is reached. Thus, as $5 \mathrm{mg} \cdot \mathrm{L}^{-1}$ is a concentration closer to that in which pharmaceuticals are found in nature (ZHOU et al., 2016), it was chosen as the basis for the kinetic study. Finally, it was found that for different initial concentrations of the pharmaceuticals, similar decay rates were obtained. 


\subsection{Kinetic study}

The kinetic study employed the best process conditions for the pharmaceuticals treatment by the $\mathrm{UV} / \mathrm{H}_{2} \mathrm{O}_{2}$ action. From the data obtained on the evolution of the pharmaceuticals conversion as a function of time, it was possible the apply the kinetic model proposed by Chan and Chu (2003). A linearization was initially performed to determine the parameters $\rho$ and $\sigma$, and then the kinetic curves obtained from the model for both pharmaceuticals were built, with the results obtained in the model being compared with the experimental data, as shown in Figure 4.

Figure 4 - Adjustment of the Chan and Chu (2003) proposed model for the pharmaceuticals: A) Lamivudine and B) Zidovudine

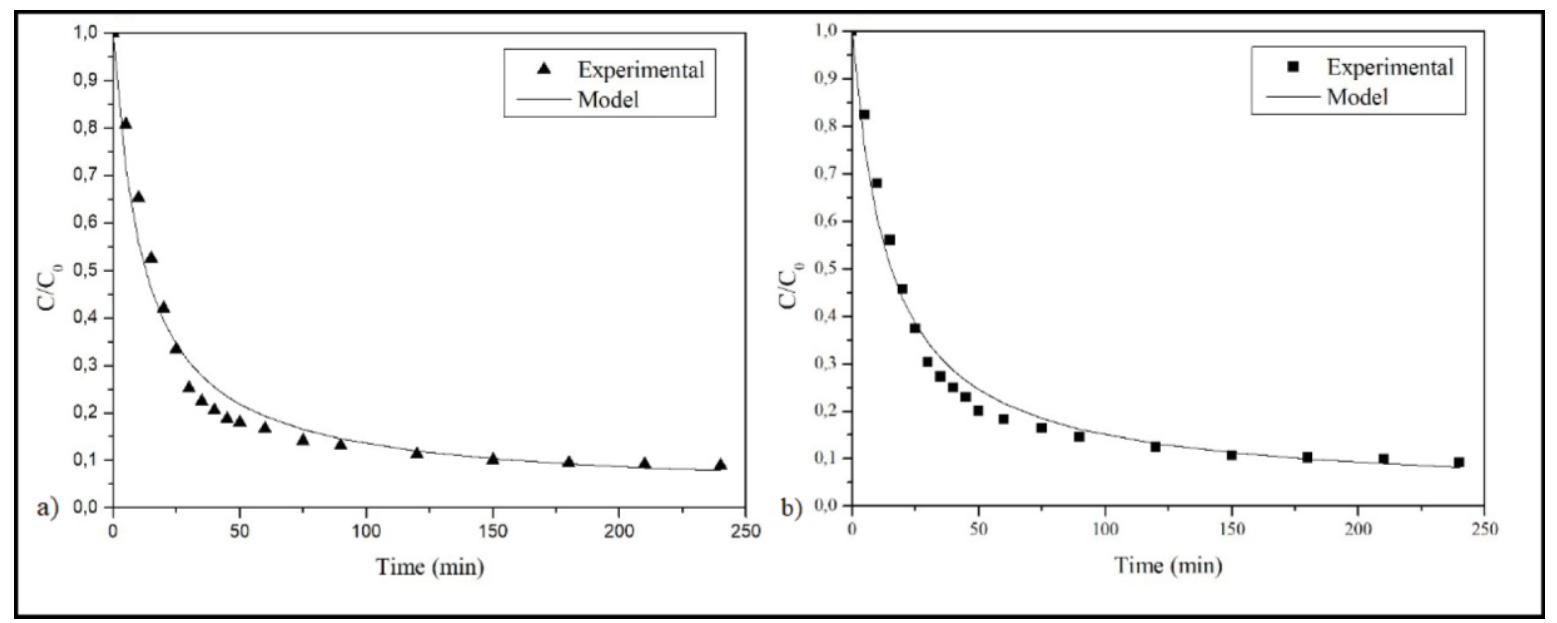

From Figure 4, it was observed that the degradation of the pharmaceuticals occurs more rapidly in the first 50 min, stabilizing after 180 min of process, reaching a degradation of at least $90 \%$ for both drugs studied. The degradation values after 180 min of treatment, the correlation coefficients and the kinetic data obtained for the applied model are shown in Table 6.

Table 6 - Parameters of the Chan and Chu (2003) kinetic model for both drugs 
Lamivudine

90.50

0.081

0.9670

0.9980

Zidovudine

89.76

0.067

0.9734

0.9978

Analyzing Table 6, it can be stated that the proposed model was satisfactorily adjusted to the experimental data, with correlation coefficient values greater than

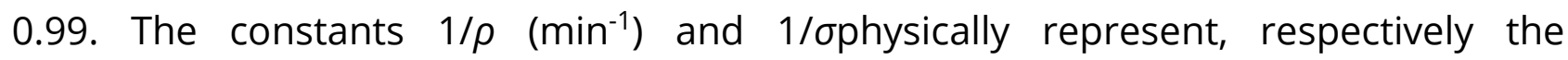
pharmaceutical removal rate and the maximum oxidative capacity in the process according to Chan and Chu (2003). Thus, from the data presented in Table 6, it was observed that lamivudine presented a higher rate of degradation while the oxidative capacity was similar for both pharmaceuticals. Another way of visualizing the adequacy of the kinetic model is to relate both data (experimental $x$ model) in the same points, as can be verified in Figure 5.

Figure 5 - Comparison between the experimental values and those obtained by the pseudo-first-order model for the pharmaceuticals: (a) Lamivudine e (b) Zidovudine

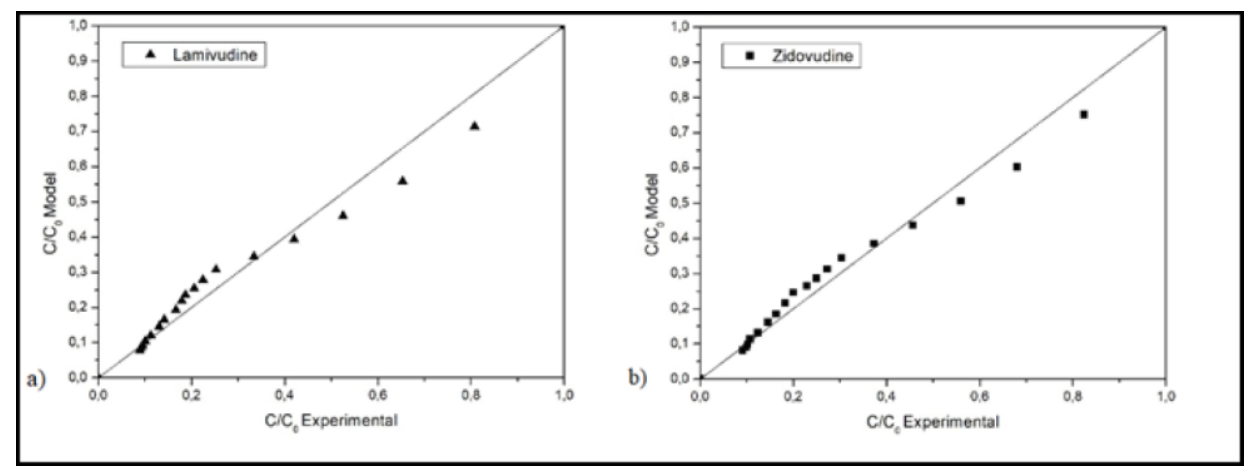

The comparison between model and experimental data exposed in Figure 5 confirms that the pseudo-first order kinetic model proposed by Chan and Chu (2003) satisfactorily describes the experimental results found in the pharmaceutical treatment employing the $\mathrm{UV} / \mathrm{H}_{2} \mathrm{O}_{2}$ process. Since the closer the experimental values are to the first bisector shown in the graphs, the better it will be to fit them in the proposed model.

After modeling the pharmaceutical degradation, the COD decay analysis was carried out over time, thus analyzing the organic matter conversion, using the model 
proposed by Rajkumar and Palanivelu (2004). From the relation $\ln \left(\frac{D Q O}{D Q O_{n}}\right)$ versus t, the graph of a straight line was obtained, whose angular coefficient represents the kinetic constant of the process, with a value of $0.0105 \mathrm{~min}^{-1}$. Using this constant obtained, the decay of the experimental COD and the one obtained by the proposed model can be compared, Figure 6A. The removal of COD stabilizes near the 90 min of process, with a degradation of $58 \%$. Figure $6 \mathrm{~B}$ shows the relationship between experimental and model data.

Figure 6 - (a) Evolution of COD decay and adjustment to the kinetic model proposed by Rajkumar and Palanivelu (2004) and (b) Comparison between experimental COD decay values and those obtained by the kinetic model proposed by Rajkumar and Palanivelu (2004)
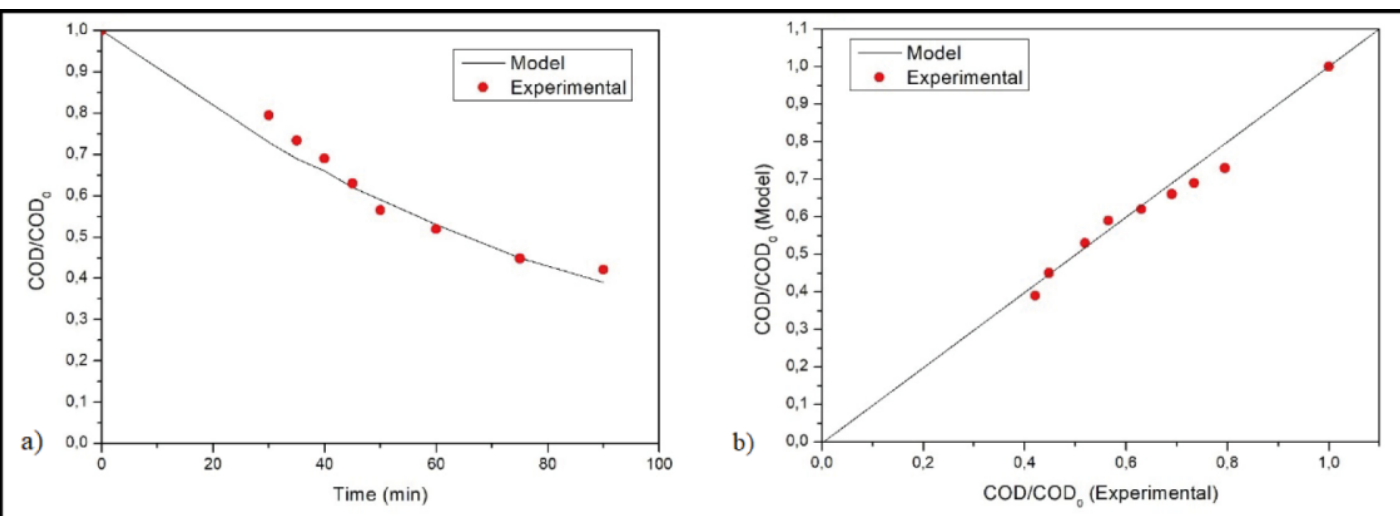

As the experimental data are grouped close to the first bisect of the graph present in Figure $6 \mathrm{~B}$, it can be stated that the model fits the experimental data and that COD kinetics for the mixture of lamivudine and zidovudine in an aqueous solution treated via $U V / \mathrm{H}_{2} \mathrm{O}_{2}$ is of first order. Finally, after defining the best working conditions and kinetic monitoring the degradation of the compounds under study by UV/Vis spectrophotometry, the AOP efficiency was verified by quantifying the drugs using HPLC, whose chromatogram can be observed in Figure 7. It was found that lamivudine degraded $97.33 \pm 0.14 \%$, while zidovudine showed a score of $93.90 \pm$ 
$0.33 \%$, indicating that the $\mathrm{UV} / \mathrm{H}_{2} \mathrm{O}_{2}$ process is efficient in the degradation of the pharmaceutical compounds studied.

Figure 7 - Chromatogram for lamivudine and zidovudine analysis

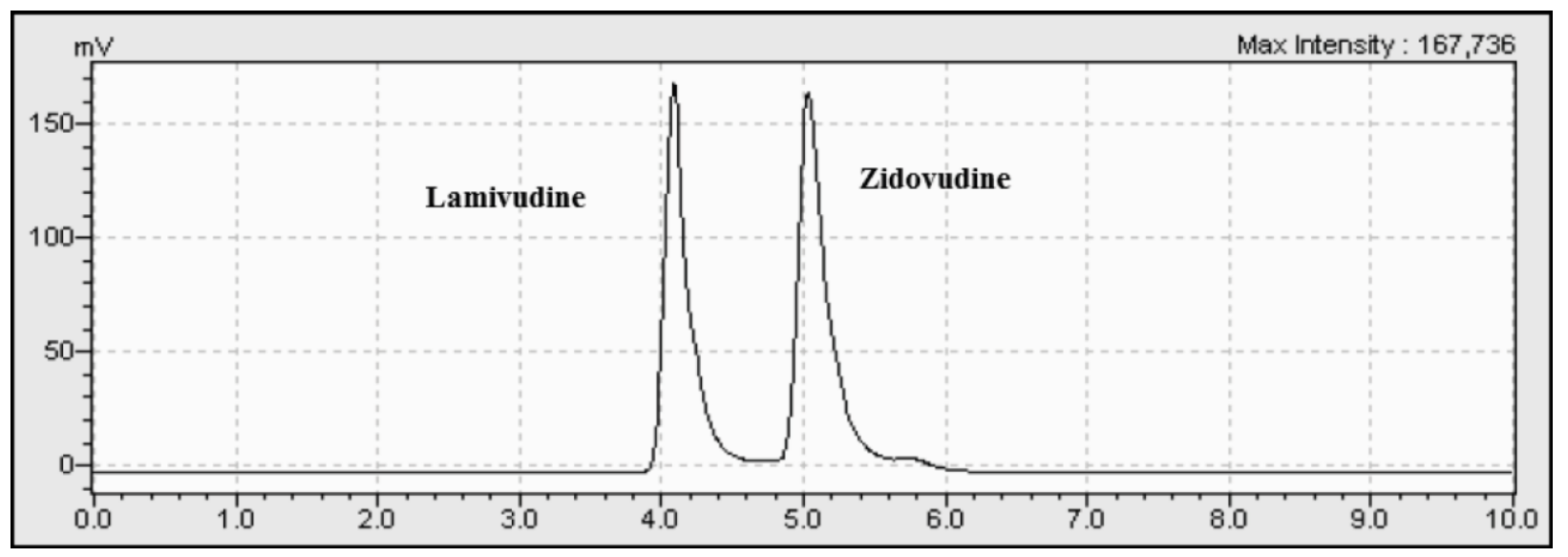

\subsection{Artificial Neural Networks}

The effects of the variables, pharmaceutical concentration, $\left[\mathrm{H}_{2} \mathrm{O}_{2}\right],[\mathrm{Fe}], \mathrm{pH}$, time, volume and $\mathrm{H}_{2} \mathrm{O}_{2}$ addition were evaluated in the $\mathrm{UV} / \mathrm{H}_{2} \mathrm{O}_{2}$ process for the degradation of a mixture of lamivudine and zidovudine drugs, by applying artificial neural networks modeling. From simulations performed using Statistica 8.0 software, it was verified that among the studied models, the MLP was the most accurate for data analysis. In this case, the best network had 23 hidden layer neurons (MLP 7-23-2) and $\mathrm{R}^{2}$ values equal to $0.999239 ; 0.999743 ; 0.999464$ for training, testing and validation, respectively. The activations functions for the input and output layers were Exponential and Logistic, with sum of squares (SOS) as an error function. The training algorithm, back propagation, was found at the 221 epoch.

The relative importance (\%) of the input variables in the efficiency of the pharmaceuticals degradation process was calculated based on the weight data of the studied layers (input, intermediate and output), obtained through the ANNs. Noting that the most influential factor in the process was the $\left[\mathrm{H}_{2} \mathrm{O}_{2}\right]$, with a significance of $55.48 \%$. For a better understanding of the contribution of each factor involved in the process, a graph with all of them was generated, Figure 8. 
Figure 8 - Model adjustments graphs for training, testing and validation of the ANN

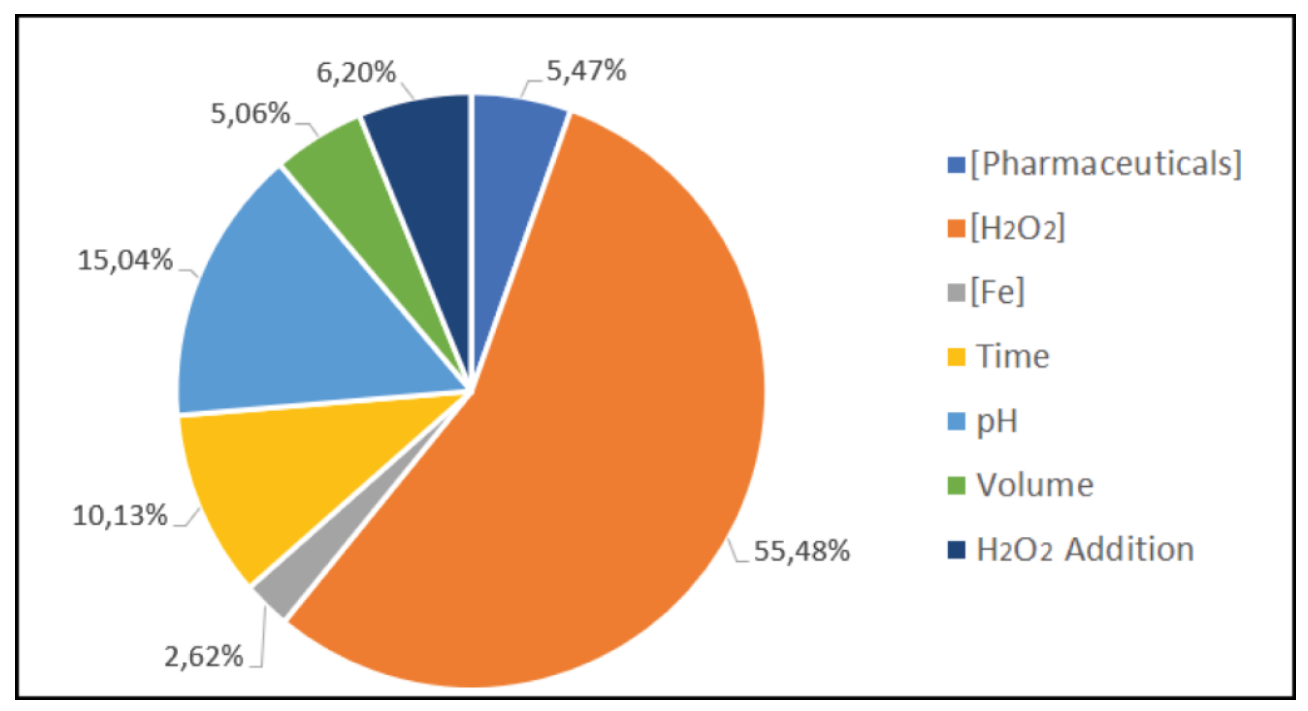

Finally, the accuracy of the ANN model developed to predict the pharmaceuticals degradation was tested. For this, the values predicted by the network were compared with those obtained experimentally, as shown in Figure 9.

Figure 9 - Parity plots of the models used for training, test and validation altogether for (a) zidovudine; (b) lamivudine

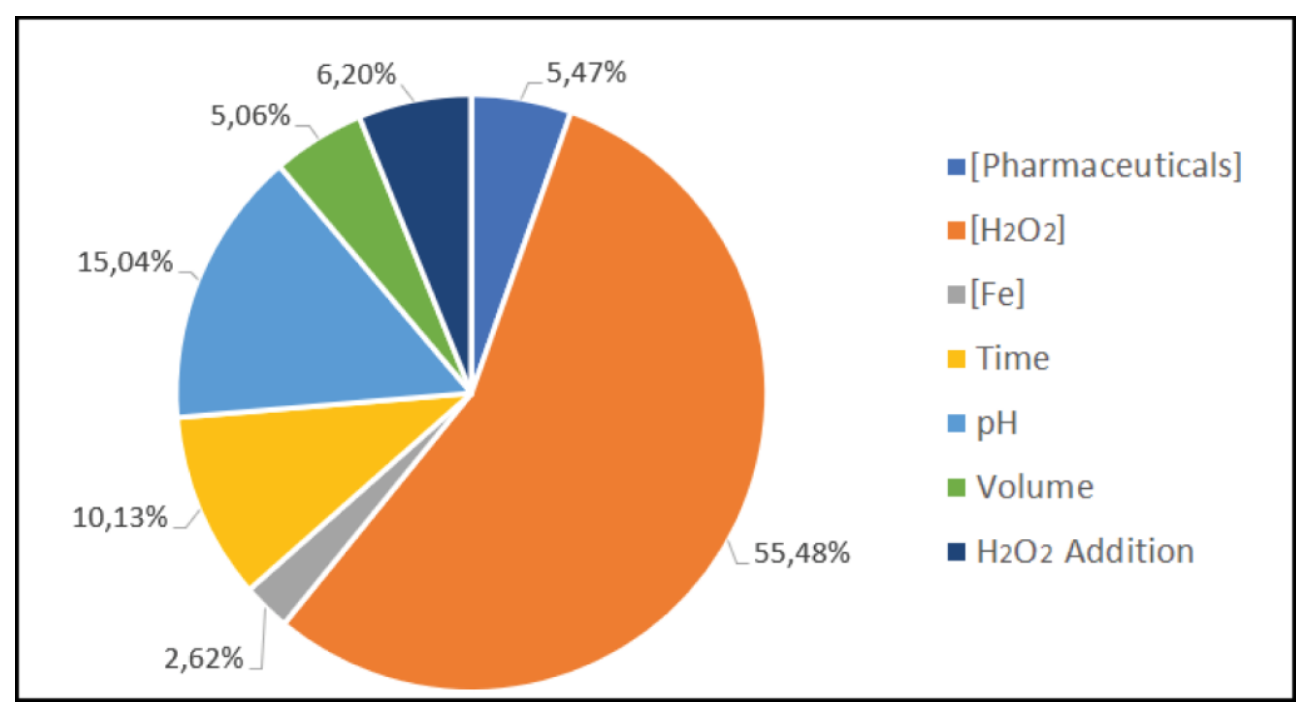

Figures 9 (a) and 9 (b) represent the comparative analysis of data grouping between calculated and experimental values for the degradation percentage between the training, testing and validation subsets, respectively for zidovudine and 
lamivudine. Analyzing these figures, it was verified the data did now show a dispersion tendency, confirming that MLP 7-23-2 topology with back propagation algorithm are adequate to evaluate the degradation performance of the lamivudine and zidovudine mixture by $\mathrm{UV} / \mathrm{H}_{2} \mathrm{O}_{2}$. The reliability of the model was verified based on the correlation coefficient obtained for the output variable, which was greater than 0.999 .

\subsection{Toxicity assessment}

The toxicity tests evaluated the presence of toxic effects of the pharmaceuticals solutions before and after the treatment by advanced oxidation processes in the seeds of Lactuca sativa and Portulaca grandiflora. The results of the triplicate assays for the amount of germinated seeds are shown in Table 7 (none of the seeds tested germinated in the presence of boric acid, positive control).

Table 7 - Mean values of germinated seeds and standard deviations

\begin{tabular}{lcc}
\hline Solution & $\begin{array}{c}\text { Germinated seeds } \\
\text { Lactuca sativa }\end{array}$ & $\begin{array}{c}\text { Germinated seeds } \\
\text { Portulacagrandiflora }\end{array}$ \\
\hline BTS & $8.67 \pm 1.16$ & $6.67 \pm 1.16$ \\
Water & $8.67 \pm 0.58$ & $9.67 \pm 0.58$ \\
PTS1\% & $9.33 \pm 0.58$ & $8.67 \pm 0.58$ \\
PTS5\% & $9.33 \pm 0.58$ & $8.33 \pm 0.58$ \\
PTS10\% & $9.33 \pm 0.58$ & $8.33 \pm 0.58$ \\
PTS50\% & $8.67 \pm 0.58$ & $8.33 \pm 0.58$ \\
PTS70\% & $8.33 \pm 0.58$ & $8.33 \pm 1.18$ \\
PTS100\% & $7.33 \pm 1.16$ & $8.00 \pm 0.00$ \\
\hline
\end{tabular}

Analyzing Table 7, it can be seen that for both the seeds Lactuca sativa and Portulaca grandiflora the post-treatment solution at 100\% (PTS100\%) presented a lower germination when compared to the negative control, so that it can be affirmed that the compounds formed after the treatment present toxicity to the legume and flower specied analyzed. It was also verified that Lactuca sativa had a greater impact. 
However, this impact is mitigated when the dilution of the post treatment solution is carried out, with the germination of concentrations 1,5 and 10\% close to the value of the negative control. The Portulaca grandiflora had its germination more affected by the before treatment solution (BTS) than by the treated solutions, and there was no greater variation in the number of seeds germinated in the different concentrations after treatment.

After the germination analysis, root growth was evaluated for both seeds, always using the length of the roots that obtained the highest growth in each of the Petri dishes used in the test. In order to obtain a more detailed view of the data, the relative growth $(R G I)$ and the germination index $(G l)$ were determined, this results are show in Table 8.

Table 8 - Mean values of root growth, RGI and GI (\%) of the seeds Lactuca sativa and Portulaca grandiflora (triplicate assays)

\begin{tabular}{lcccccc}
\hline \multirow{2}{*}{ Solution } & \multicolumn{2}{c}{ Root lenght $(\mathbf{c m})$} & RGI & GI (\%) & RGI & GI (\%) \\
\cline { 2 - 6 } & Lactuca sativa & Portulaca grandiflora & Lactuca sativa & Portulaca grandiflora \\
\hline Water & $5.83 \pm 0.416$ & $2.43 \pm 0.153$ & 1.00 & 100.00 & 1.00 & 100.00 \\
BTS & $4.53 \pm 0.153$ & $1.83 \pm 0.153$ & 0.78 & 69.67 & 0.75 & 51.96 \\
PTS1\% & $5.73 \pm 0.058$ & $2.30 \pm 0.100$ & 0.98 & 94.90 & 0.94 & 81.48 \\
PTS5\% & $5.67 \pm 0.208$ & $2.23 \pm 0.058$ & 0.97 & 93.79 & 0.92 & 79.12 \\
PTS10\% & $5.60 \pm 0.100$ & $2.10 \pm 0.200$ & 0.96 & 96.00 & 0.86 & 74.40 \\
PTS50\% & $5.57 \pm 0.208$ & $2.10 \pm 0.100$ & 0.95 & 85.56 & 0.86 & 74.40 \\
PTS70\% & $5.30 \pm 0.200$ & $2.10 \pm 0.153$ & 0.91 & 78.33 & 0.86 & 74.40 \\
PTS100\% & $3.00 \pm 0.200$ & $1.97 \pm 0.153$ & 0.51 & 39.01 & 0.81 & 66.89 \\
\hline
\end{tabular}

From Table 8 it can be seen that in the higher concentrations of the posttreatment solution an inhibition of the root growth of the two seeds studied was verified, proving that after treatment by $\mathrm{UV} / \mathrm{H}_{2} \mathrm{O}_{2}$ not only the germination suffers impact, but also the development of the seeds studied. The root growth decreases as 
the concentration of post-treatment solution increases, especially to $100 \%$. The reduction of root growth index especially affects the Lactuca sativa.

According to Young et al. (2012) any seed growth result that is less than $80 \%$ $(R G \mid<0.8)$ of the value of the negative control is considered to have undergone growth inhibition. It is then realized that the solution prior to the treatment inhibits the growth of both seeds and that the post treatment solution inhibits the growth of Lactuca sativa, i.e., exhibits toxicity.

This toxicity can be minimized by the purifying power of the recipient bodies. That was observed through the dilution assays of the post-treatment solutions. In which the root growth showed values close to those of the negative control (relative growth indexes, RGI, close to 1) in the tests inferior to the PTS70\%, not compromising, in these conditions, the growth of the two seeds studied.

\section{CONCLUSIONS}

The present work involving the application of the advanced oxidation processes for the degradation of lamivudine and zidovudine pharmaceuticals obtained encouraging results. With a degradation of $97.33 \pm 0.14 \%$ of lamivudine and $93.90 \pm$ $0.33 \%$ of zidovudine after 180 minutes of treatment by $\mathrm{UV} / \mathrm{H}_{2} \mathrm{O}_{2}$ process in a UV-C reactor. Kinetic models of pseudo-first order were used to monitor the temporal decay of the pharmaceutical concentration and for the conversion of the organic matter through the COD during the process, these being represented satisfactorily with values of $\mathrm{R}^{2}$ and rate constants of 0.9980 and $0.081 \mathrm{~min}^{-1}$ for lamivudine and 0.9978 and $0.067 \mathrm{~min}^{-1}$ for zidovudine, respectively. For COD follow-up, the values obtained for these two parameters were 0.9705 for lamivudine and $0.0105 \mathrm{~min}^{-1}$ for zidovudine. It was possible to apply a mathematical model by artificial neural networks of the Multilayers Percepton type (7-23-2) to predict the pharmaceuticals degradation percentages, as well as to determine the relative importance of each of the input variables involved in the degradation process, with the most significant one 
being the $\mathrm{H}_{2} \mathrm{O}_{2}$ concentration, with $55.48 \%$. The toxicity analyzes showed that there in inhibition of germination, as well as root growth, for both species, Lactuca sativa and Portulaca grandiflora when in contact with untreated pharmaceutical solutions, and that Lactuca sativa is also affect by the treated solution, presenting toxicity in these cases. However, this can be mitigated by the purification power of the recipient bodies, there being no record of toxicity and consequently of significant impairment of the two seeds studied when evaluating trials where the post treatment solution was in concentrations lower than $70 \%$.

\section{ACKNOWLEDGEMENT}

To NUQAAPE/FACEPE, CAPES and FADE/UFPE.

\section{REFERENCES}

AMERICAN PUBLIC HEALTH ASSOCIATION - (APHA). Standard methods for the examination of water and wastewater. $22^{\text {nd }}$ ed. Washington, D.C; 2012.

AMETA CS, AMETA R, editors. Advanced Oxidation Process for Wastewater Treatment: Emerging Green Chemical Technology. 1st ed. Academic Press; 2018.

AMINOT $Y$, LITRICO $X$, CHAMBOLLE $M$, ARNAUD C, PARDON P, BUDZINDKI H. Development and application of a multi-residue method for the determination of 53 pharmaceuticals in water, sediment, and suspended solids using liquid chromatography-tandem mass spectrometry. Anal. Bioanal. Chem. 2015; 407(58):8585-8605.

AQUINO SF, BRANDT EMF, CHERNICHARO, CAL. Remoção de fármacos e desreguladores endógenos em estações de tratamento de esgoto: revisão da literatura. Engen. Saint. Ambient. 2013; 18(3):187-204.

ARABZADEH V, SOHRABI MR, GOUDARZI N, DAVALLO M. Using artificial neural network and multivariate calibration methods for simultaneous spectrophotometric analysis of Emtricitabine and Tenofovir alafenamide fumarate in pharmaceutical formulation of HIV drug. Spectrochimica Acta Part A: Molecular and Biomolecular Spectroscopy. 2019; 215:266-275. 
BEKKARI N, ZEDDOURI A. Using artificial neural network for predicting and controlling the effluent chemical oxygen demand in wastewater treatment plant. Management of Environmental Quality. 2019; 30(3):593-608.

BIALK-BIELINSKA A, KUMIRSKA J, BORECKA M, CABAN M, PASZKIEWICZ M, PAZDRO K, STEPNOWSKI P. Selected analytical challenges in the determination of pharmaceuticals in drinking/marine waters and soil/sediment samples. J. Pharm. Biomed. Anal. 2016; 121:271-296.

BOTTONI P, CAROLI S, CARACCIOLO AB. Pharmaceuticals as priority water contaminants. Toxicol. Environ. Chem. 2010; 92(3):549-565.

BRANDT MJ, JOHNSON KM, ELPHINSTON AJ, RATNAYAKA DD. Twort's Water Supply. 7th ed. Elsevier; 2017.

BRASIL, MINISTÉRIO DA SAÚDE. Resolução No 899/2003. Agência Nacional de Vigilância Sanitária - (ANVISA). Brasília (Brasil): Ministério da Saúde; 2003.

BURKE LA, MARKS KM. Drugs to Treat Viral Hepatitis. In: COHEN J, POWDERLY WG, OPAL SM, editors. Infectious Diseases. 4th ed. Elsevier Ltd; 2017. p. 1327-1332.

CAMPONESCHI G, FAST J, GAUVAL M, GUERRA K, MOORE M, RAVINUTALA S, RIPIN D, SHEPEL V. An overview of the antiretroviral market. Current Opinion in HIV and AIDS. 2013; 8(6):535-543.

$\mathrm{CHAN} \mathrm{KH}, \mathrm{CHU}$ W. Modeling the reaction kinetics of Fenton's process on the removal of atrazine. Chemosphere. 2003;51(4):305-311.

CHRISTOU A, KARAOLIA P, EVROULA H, MICHAEL C, FATTA-KASSINOS D. Long-term wastewater irrigation of vegetables in real agricultural systems: Concentration of pharmaceuticals in soil, uptake and bioaccumulation in tomato fruits and human health risk assessment. Water Res. 2017; 109:24-34.

CORBETT M. A brief history of AZT. National Museum of American History [Internet]. 2010. Available from: http://americanhistory.si.edu/blog/2010/09/a-brief-history-ofazt.html.

EBELE AJ, ABDALLAH MA-E, HARRAD S. Pharmaceuticals and personal care products (PPCPs) in the freshwater aquatic environment. Emerging Contaminants. 2017; 3(1):116.

EXPÓSITO AJ, MONTEAGUDO JM, DURÁN A, SAN MARTíN I, GONZÁLEZ L. Study of the intensification of solar photo-Fenton degradation of Carbamazepine with Ferrioxalate Complexes and Ultrasound. J. Hazard Mater. 2018; 342:597-605.

FUNKE J, PRASSE C, TERNES TA. Identification of transformation products of antiviral drugs formed during biological wastewater treatment and their occurrence in the urban water cycle. Water Res. 2016; 98:75-83. 
GAD SC. Handbook of Pharmaceutical Biotechnology. 1st ed. 2007. WILEYINTERSCIENCE.

GIANNAKIS S, HENDAOUI I, RTIMI S, FURBRINGER JM, PULGARIN C. Modeling and treatment optimization of pharmaceutically active compounds by the photo-Fenton process: The case of the antidepressant venlafaxine. J. Environ. Chem. Eng. 2017; 5(1):818-828.

GIRI AS, GOLDER AK. Decomposition of drug mixture in Fenton and photo-Fenton processes: Comparison to singly treatment, evolution of inorganic ions and toxicity assay. Chemosphere. 2015; 127:254-261.

GRUBBS FE, BECK G. Extension of sample Sizes and Percentage points for Significance Tests of Outlying Observations. Technometrics. 1972; 14(4):847-854.

HUANG N, WANG T, WANG W-L, WU Q-Y, LI A, HU H-Y. UV/chlorine as an advanced oxidation process for the degradation of benzalkonium chloride: Synergistic effect, transformation products and toxicity evaluation. Water Res. 2017; 114:246-253.

INSTITUTO NACIONAL DE METROLOGIA, QUALIDADE E TECNOLOGIA. DOC-CGCRE-008 Orientação sobre validação de métodos analíticos. Brasília (Brasil): INMETRO; 2016.

IOANNOU-TTOFA L, RAJ S, PRAKASH H, FATTA-KASSINOS, D. Solar photo-Fenton oxidation for the removal of ampicillin, total cultivable and resistant $\mathrm{E}$. coli and ecotoxicity from secondary-treated wastewater effluents. Chem. Eng. J. 2019; 355:91102.

KARISHMA S, SUBRAMANIAM S, MUTHURAMAN MS, SIVASUBRAMANIAN A. RP-HPLC Method development and validation for lamivudine and zidovudine in pharmaceutical dosage forms. Int. J. Pharmtech. Res. 2013; 5(3):1321-1331.

KLAVARIOTI M, MANTZAVINOS D, KASSINOS D. Removal of residual pharmaceuticals from aqueous systems by advanced oxidation processes. Environ. Int. 2009; 35:402417.

K'OREJE KO, DEMEESTERE K, WISPELAERE PD, VERGEYNST L, DEWULF J, LANGENHOVE $\mathrm{HV}$. From multi-residue screening to target analysis of pharmaceuticals in water: Development of a new approach based on magnetic sector mass spectrometry and application in the Nairobi River basin, Kenya. Sci. Total Environ. 2012; 437:153-164.

K'OREJE KO, VERGEYNST L, OMBAKA D, WISPELAERE PD, OKOTH M, LANGENHOVE HV, DEMEESTERE K. Occurrence patterns of pharmaceutical residues in wastewater, surface water and groundwater of Nairobi and Kisumu city, Kenya. Chemosphere. 2016:149:238-244. 
KUMARI G, SINGH RK. Highly Active Antiretroviral Therapy for treatment of HIV/AIDS patients: Current status and future prospects and the Indian scenario. HIV \& AIDS Review. 2012; 11(1):5-14.

LAVRA ZMM, NETO PJR, da SILVA RMF, de MEDEIROS FPM. Desenvolvimento e Validação de Método Analítico para determinação simultânea de Lamivudina, Zidovudina e Nevirapina em comprimidos dose-fixa combinada por cromatografia de alta eficiência. Quim. Nova. 2008; 31(5):969-974.

LI Y, IGNE B, DRENNEM III JK, ANDERSON CA. Method development and validation for pharmaceuticals tablets analysis using Raman spectroscopy. Int. J. Pharm. 2016; 498:318-325.

LINDEN KG, MOHSENI M. Advanced Oxidation Processes: Applications in Drinking Water Treatment. Comprehensive Water Quality and Purification. 2014; 2:148-172.

LOCATELLI, M, SCIASCIA, F, CIFELLI, R, MALATESTA, L, PANTALEONE, B, CROCE, F. Analytical methods for the endocrine disruptor compounds determination in environmental water samples. J. Chromatogr. A. 2016; 1439:1-18.

LIU T, YIN K, LIU C, LUO J, CRITTENDEN J, ZHANG W, LUO S, HE Q, DENG Y, LIU H, ZHANG D. The role of reactive oxygen species and carbonate radical in oxcarbazepine degradation via UV, UV/ $\mathrm{H}_{2} \mathrm{O}_{2}$ : Kinetics, mechanisms and toxicity evaluation. Water Res. 2018; 147:204-213.

MADIKIZELA LM, TAVENGWA NT, CHIMUKA L. Status of pharmaceuticals in African water bodies: Occurrence, removal and analytical methods. J. Environ. Manage. 2017; 193:221-220.

MIRZAEI A, CHEN Z, HAGHIGTHAT F, YERUSHALMI L. Removal of pharmaceuticals from water by homo/heterogonous Fenton-type processes - A review. Chemosphere. 2017; 174:665-688.

MORIJI A, VAKILI M, FARRAJI H, AZIZ SQ. Combined ozone oxidation process and adsorption methods for the removal of acetaminophen and amoxicillin from aqueous solution, kinetic and optimization. Environ. Technol. Inno. 2019; 15(100404).

NAPOLEÃO DC, ZAIDAN LEMC, RODRÍGUEZ-DÍAZ JM, SANTANA RM da R, MONTENEGRO MCB da S de M, ARAÚJO A da N, BENACHOUR M, da SILVA VL. Use of the photo-Fenton process to discover the degradation of drugs present in water from Wastewater Treatment Plants of the Pharmaceutical industry. Afinidad. 2018; 75(581):23-31.

NATIONAL IMMUNE MONITORING LABORATORY - (NIML). Activity/expertise profile. INFECTIOLOGY. University of Montreal (Canada); 2010. 
NGUMBA E, GACHANJA A, TUHKANEN T. Occurrence of selected antibiotics and antiretroviral drugs in Nairobi River Basin, Kenya. Sci. Total. Environ. 2016; 539:206213.

PAÍGA P, SANTOS LHMLM, DELERUE-MATOS C. Development of a multi-residue method for the determination of human and veterinary pharmaceutical and some of their metabolites in aqueous environmental matrices by SPE-UHPLC-MS/MS. J. Pharm. Biomed. Anal. 2017; 135:75-86.

PEAKE BM, BRAUND R, TONG AYC, TREMBLAY LA. The Life-Cycle of Pharmaceuticals in the Environment. Cambridge: ELSEVIER; 2016.

PERLATTI B, SILVA MFGF, FERNANDES JB, FORIM, MR. Validation and application of HPLC-ESI-MS/MS method for the quantification of RBBR decolorization, a model for highly toxic molecules, using several fungi strains. Bioresour. Technol. 2012; 124:3744.

PRASSE C, SCHLUSENER MP, SCHULZ R, TERNES TA. Antiviral drugs in wastewater and surface water: A new pharmaceutical class of environmental relevance?. Environ. Sci. Technol. 2010; 44:1728-1735.

QIU W, ZHENG M, SUN J, TIAN Y, FANG M, ZHENG Y, ZHANG T, ZHENG C. Photolysis of enrofloxacin, pefloxacin and sulfaquinoxaline in aqueous solution by $U V / \mathrm{H}_{2} \mathrm{O}_{2}$, $\mathrm{UV} / \mathrm{Fe}(\mathrm{II})$, and $\mathrm{UV} / \mathrm{H}_{2} \mathrm{O}_{2} / \mathrm{Fe}(\mathrm{II})$ and the toxicity of the final reaction solutions on zebrafish embryos. Sci. Total. Environ. 2019; 651:1457-1468.

RAJKUMAR D, PALANIVELU K. Electrochemical treatment of industrial wastewater. J. Hazard. Mater. 2004; 133(1-3):123-129.

RIBANI M, BOTTOLI CBG, COLLINS CH, JARDIM ICSF, MELO LFC. Validação em métodos cromatográficos e eletroforéticos. Quim. Nova. 2004; 27(5):771-780.

RIBEIRO AR, NUNES OC, PEREIRA MFR, SILVA AMT. An overview on the advanced oxidation processes applied for the treatment of water pollutants defined in the recently launched Directive 2013/39/EU. Environ. Int. 2015; 75:33-51.

RODRIGUEZ-NARVAEZ OM, PERALTA-HERNANDEZ JM, GOONETILLEKE A, BANDALA ER. Treatment Technologies for emerging contaminants in water: a review. Chem. Eng. J. 2017; 323:361-380.

ROMERO V, GONZÁLEZ O, BAYARRI B, MARCO P, GIMÉNEZ J, ESPLUGAS S. Degradation of Metoprolol by photo-Fenton: Comparison of different photoreactors performance. Chem. Eng. J. 2016; 283:639-648.

SALVADOR T, MARCOLINO JRLH, PERALTA-ZAMORA P. Degradação de corantes têxteis e remediação de resíduos de tingimento por Processos Fenton, Foto-Fenton e EletroFenton. Quim. Nova. 2012:35(5):932-938. 
SANDERSON H, JOHNSON DJ, REISMA T, BRAIN RA, WILSON CJ, SOLOMON KR. Ranking and prioritization of environmental risks of pharmaceuticals in surface waters. Regul. Toxicol. Pharmacol. 2004; 39(2):158-183.

SERPONE N, ARTEMEV YM, RYABCHUK VK, EMELINE AV, HORIKOSHI S. Light-driven advanced oxidation processes in the disposal of emerging pharmaceutical contaminants in aqueous media: A brief review. Curr. Opin. Green Sustainable Chem. 2017; 6:18-33.

SCHOEMAN, C.; DLAMINI, M.; OKONKWO, O. J. The impact of a Wastewater Treatment Works in Southern Gauteng, South Africa on efavirenz and nevirapine discharges into the aquatic environment. Emerging Contaminants. 2017; 3:95-106.

TIBURTIUS, E. R. L.; PERALTA-ZAMORA, P.; EMMEL, A. Degradação de benzeno, tolueno e xilenos em águas contaminadas por gasolina, utilizando-se processos foto-Fenton. Quim. Nova. 2009;32(8):2058-2063.

JOINTED UNITED NATIONS ON HIV/AIDS (UNAIDS) - Global AIDS Update, 2016. Available in: http://www.unaids.org/sites/default/files/media_asset/global-AIDSupdate-2016_en.pdf.

UNITED STATES ENVIRONMENTAL PROTECTION AGENCY.EPA/625/R-98/004. Handbook on Advanced Photochemical Oxidation Processes. Washington, D.C. (USA): USEPA; 1998.

VERGEYNST L, HAECK A, WISPELAERE PD, LANGENHOVE HV, DEMEESTERE K. Multiresidue analysis of pharmaceuticals in wastewater by liquid chromatographymagnetic sector mass spectrometry: Method quality assessment and application in a Belgian case study. Chemosphere. 2015a; 119:52-58.

VERGEYNST L, LANGENHOVE HV, DEMEESTERE K. Balancing the False Negative and Positive Rates in Suspect Screening with High-Resolution Orbitrap Mass Spectrometry Using Multivariate Statistics. Anal. Chem. 2015b;87(4):2170-2177.

WANG J, WANG S. Removal of pharmaceuticals and personal care products (PPCPs) from wastewater: A review. J. Environ. Manage. 2016; 182:620-640.

WOOD TP, DUVENAGE CSJ, ROHWER E. The occurrence of anti-retroviral compounds used for HIV treatment in South African surface water. Environ. Pollut. 2015; 199:235243.

WOOD TP, PREEZ CD, STEENKAMP A, DUVENAGE C, ROHWER ER. Database-driven screening of South African surface water and the targeted detection of pharmaceuticals using liquid chromatography - High resolution mass spectrometry. Environ. Pollut. 2017; 230:453-462. 
YANG Y, CAO Y, JIANG J, LU X, MA J, PANG S, LI J, LIU Y, ZHOU Y, GUAN C. Comparative study on degradation of propranolol and formation of oxidation products by $U V / \mathrm{H}_{2} \mathrm{O}_{2}$ and UV/persulfate (PDS). Water Res. 2019; 149:543-552.

YOUNG BJ, RIERA NI, BEILY ME, BRES PA, CRESPO DC, RONCO AE. Toxicity of the effluent from an anaerobic bio reactor treating cereal residues on Lactuca sativa. Ecotoxicol. Environ. Saf. 2012; 76:182-186.

ZAIDAN LEMC, PINHEIRO RB, SANTANA RM da R, CHARAMBA LVC, NAPOLEÃO DC, da SILVA VL. Evaluation of efficiency of advanced oxidative process in degradation of 2-4 dichlorophenol employing UV-C radiation reactor. REGET. 2017;21(2):147-157.

ZHOU C, CHEN J, XIE Q, WEI X, ZHANG Y-N, FU Z. Photolysis of three antiviral drugs acyclovir, zidovudine and lamivudine in surface freshwater and sea water. Chemosphere. 2015; 138:792-797.

ZHOU H, YING T, WANG X, LIU J. Occurrence and preliminarily environmental risk assessment of selected pharmaceuticals in the urban rivers, China. Sci. Rep. 2016;6(34928). 